\title{
Analisis Kinerja GPSR dan AODV pada VANET dengan Skema Pengimbangan Beban Trafik
}

\author{
RENDI DIAN PRASETIA, DOAN PERDANA, RIDHA MULDINA NEGARA
}

Teknik Telekomunikasi, Fakultas Teknik Elektro, Universitas Telkom

Email : prasetia.rendi.rdp@gmail.com

Received 1 Maret 2018 | Revised 16 April 2018 | Accepted 28 Mei 2018

\begin{abstract}
ABSTRAK
Salah satu permasalahan di kota-kota besar adalah kemacetan lalu lintas yang disebabkan karena tidak mencukupinya ruas jalan, volume kendaraan yang begitu besar, persebaran kendaraan yang tidak merata dan lain-lain. Salah satu solusinya adalah para pengendara dapat menggunakan aplikasi peta digital pada smartphone-nya. Oleh karena itu perlu dilakukan pengimbangan beban trafik kendaraan. Pada penelitian ini akan dibahas mengenai kinerja VANET yang menggunakan protokol routing GPSR dan AODV dengan skema pengimbangan beban trafik kendaraan dengan pengaruh kepadatan node. Perancangan sistem simulasi terbagi menjadi dua subsistem yaitu subsistem mobilitas dan jaringan. Kemudian dilakukan pengimbangan beban trafik kendaraan, dan kinerja VANET akan diamati. Performansi dievaluasi dengan average end to end delay, throughput, dan packet delivery ratio. Nilai rata-rata throughput, $P D R$, delay untuk GPSR adalah 142.21 Kbps, $87.47 \%$, dan $82.83 \mathrm{~ms}$. Sedangkan AODV adalah $119.81 \mathrm{Kbps}, 86.67 \%$, dan $103.21 \mathrm{~ms}$. Dari hasil penelitian nilai QoS performansi dari routing protocol GPSR lebih baik dari pada AODV pada VANET.
\end{abstract}

Kata kunci: Vanet, Pengimbangan Beban, GPSR, AODV.

\begin{abstract}
One of the problems in big cities is congestion. The congestion is caused by insufficient road segment, large volume of vehicles, unbalanced spread of vehicles and others. One solution is that riders can use digital map applications on their smartphones. Therefore it is necessary to balancing the traffic load of vehicles. In this research will be discussed about VANET performance using GPSR and AODV routing protocol with vehicle traffic load balancing scheme with node density influence. The design of the simulation system is divided into two subsystems namely mobility and network subsystem. Then balancing the vehicle traffic load, and VANET performance will be observed. Performance is evaluated with the average end to end delay, throughput, and packet delivery ratio. The mean value of throughput, PDR, delay for GPSR respectively $142.21 \mathrm{Kbps}$, $87.47 \%$, and $82.83 \mathrm{~ms}$. While AODV is $119.81 \mathrm{Kbps}, 86.67 \%$, and $103.21 \mathrm{~ms}$. From the simulation results can be concluded that the performance of GPSR is better than AODV on VANET.
\end{abstract}

Keywords: Vanet, Load Balancing, GPSR, AODV. 


\section{PENDAHULUAN}

Vehicular Ad-hoc Networks (VANET) adalah suatu jaringan ad-hoc yang bersifat selforganizing yang bekerja pada sistem intervehicle communication (IVC) dan vehicle-toinfrastructure communication yang juga merupakan subkelas dari mobile ad-hoc network (MANET) (Jerome, 2009). Saat ini VANET menjadi salah satu area riset yang berkembang di beberapa tahun terakhir guna mendukung Intelligent Transportation System (ITS) (LABKBJ, 2016). Salah satu permasalahan di kota-kota besar adalah kemacetan lalu lintas. Kemacetan ini disebabkan karena tidak mencukupinya ruas jalan, volume kendaraan yang begitu besar, persebaran kendaraan yang tidak merata dan lain-lain. Kemacetan harus segera diatasi, agar tidak menyebabkan kerugian yang semakin besar. Salah satu solusinya adalah para pengendara dapat menggunakan aplikasi peta digital pada smartphone-nya.

Aplikasi peta digital seperti Google Maps, Waze menggunakan skema pengimbangan beban trafik kendaraan yang dapat menentukan rute terbaik dengan waktu tempuh terpendek. Keadaan riil yang dialami adalah ketika suatu ruas jalan mengalami kepadatan dan pengendara dapat mencari alternatif jalan dengan kepadatan kendaraan yang rendah melalui aplikasi peta digital. Dengan asumsi seperti itu dapat diasumsikan bahwa pada masa yang akan datang model mobilitas kendaraan akan sesuai dengan skema pengimbangan beban trafik kendaraan, yaitu kendaraan akan tersebar pada ruas-ruas untuk mencapai waktu tempuh terpendek. VANET dapat diimplementasikan pada kendaraan, sehingga memungkinkan kendaraan dapat saling berkomukasi. Oleh karena itu, tujuan dari penelitian ini adalah menganalisis kinerja jaringan VANET dengan model mobilitas kendaraan seperti yang telah diasumsikan sebelumnya dengan menggunakan layanan Data dan Voice serta dengan perbedaan jumlah kendaraan.

Pada penelitian sebelumnya oleh Muhtadi dkk (Muhtadi, 2015), peneliti menggunakan Routing Protocol AODV, ZRP, DSDV. Ketiga routing protocol tersebut termasuk dalam Topology Based Routing. Pada penelitian ini penulis akan menggunakan routing protocol GPSR yang termasuk Geographic Based routing dan routing protocol AODV yang termasuk dalam Topology Based Routing. GPSR (Greedy Perimeter Stateless Routing) adalah routing protocol yang bekerja dengan menggunakan informasi geografis pada tiap node-nya untuk mencari dan menemukan node terdekat yang digunakan untuk membentuk jalur routing. AODV (Ad-hoc On-demand Distance Vector) adalah routing protocol yang bekerja menggunakan table routing pada pengiriman paketnya. Hasil penelitian akan dibandingkan

antara kedua routing protocol tersebut, sehingga dapat diambil kesimpulan routing protocol yang lebih baik.

\section{PERANCANGAN SISTEM}

\subsection{Perancangan Model Mobilitas}

Pada penelitian ini dirancang model mobilitas yang menunjukan skema pengimbangan beban trafik kendaraan. Pada penelitian ini digunakan suatu perangkat lunak pembuat model mobilitas kendaraan yang bernama VanetMobiSim versi 2.0. Vanetmobisim dapat menghasilkan pola pergerakan kendaraan secara rinci menggunakan mode makro dan mikro yang berbeda, dan mempertimbangkan interaksi keduanya. Serta dapat mensimulasikan kondisi lalu lintas yang berbeda melalui skenario yang dapat disesuaikan sepenuhnya (Perdana \& Sari, 2015). Dalam membentuk model mobilitas yang semirip mungkin dengan aslinya dalam penelitian ini menggunakan data yang didapat dari observasi secara langsung. Sedangkan untuk pembuatan petanya digunakan koordinat yang diperoleh dari file Open Street Map (OSM) sehingga peta yang dihasilkan akan sesuai dengan ukuran yang sebenarnya. 
Langkah awal dalam pembuatan model mobilitas dengan data riil adalah menentukan wilayah yang akan digunakan. Penentuan wilayah ini menggunakan perangkat lunak VanetMobiSim sebagai antarmukanya dan OpenStreetMap sebagai sumber peta ini diambil. Wilayah yang dipilih pada penelitian ini dapat dilihat pada Gambar 1.

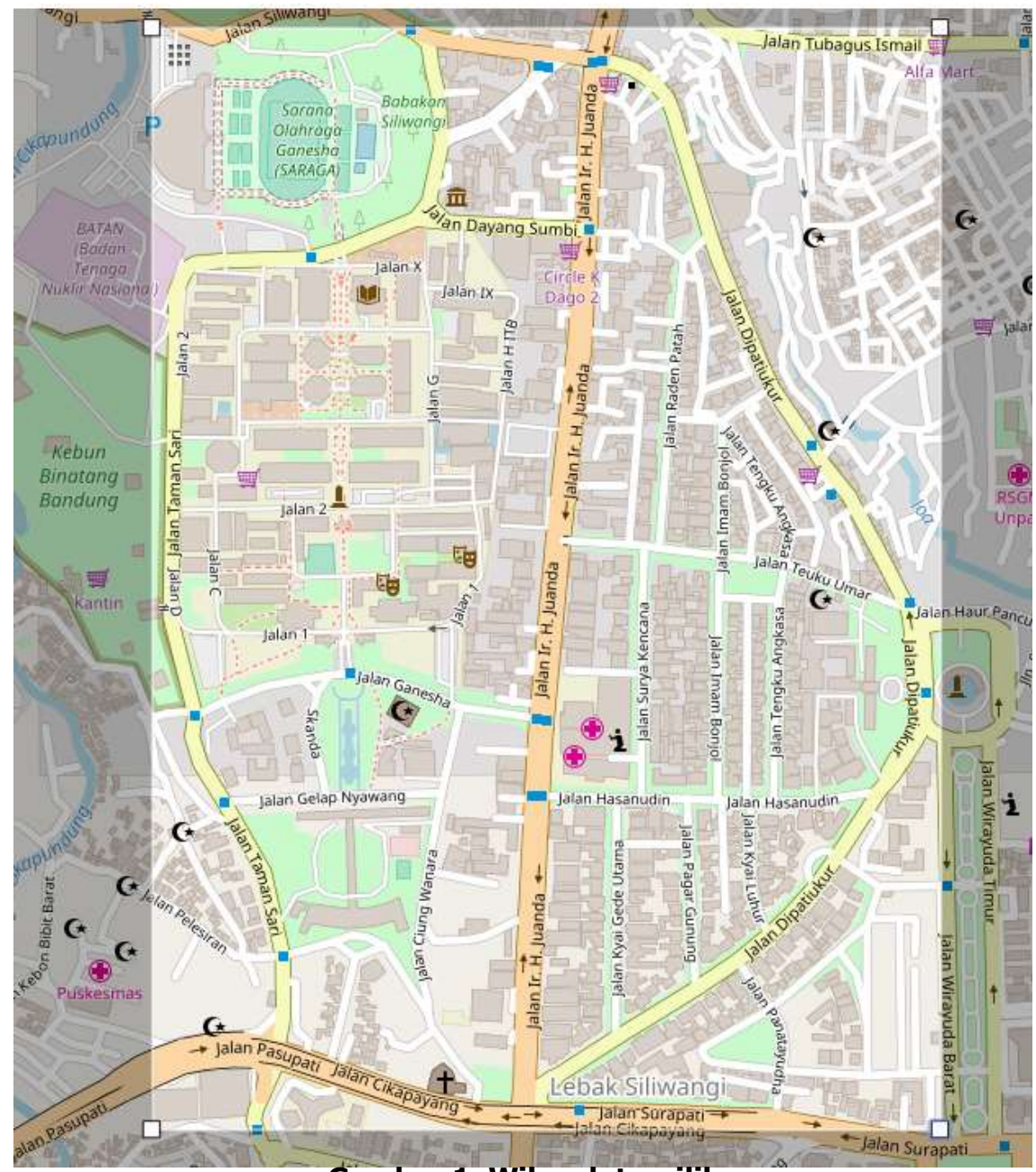

Gambar 1. Wilayah terpilih

Peta dibuat secara manual menggunakan modul User Graph pada VanetMobisim. Dalam modul User Graph dapat mengatur beberapa parameter seperti jumlah jalur, jenis kendaraan yang dapat melintas, serta kecepatan maksimum pada jalur. Hasil dari pembuatan peta menggunakan modul User Graph ini dapat dilihat pada Gambar 2.

Langkah selanjutnya adalah menentukan prilaku pengendara untuk wilayah yang digunakan. Perilaku pengendara adalah parameter-parameter yang membentuk perilaku dalam berkendara. Parameter tersebut diantaranya kecepatan dan percepatan kendaraan, dan metode pemilihan rute perjalanan. Untuk membentuk perilaku pengendara dengan parameter tersebut maka digunakan suatu model mobililtas yang bernama Intelligent Driver Model with Intersection Management (IDM-IM) yang dikembangkan oleh Institut Eurecom. 


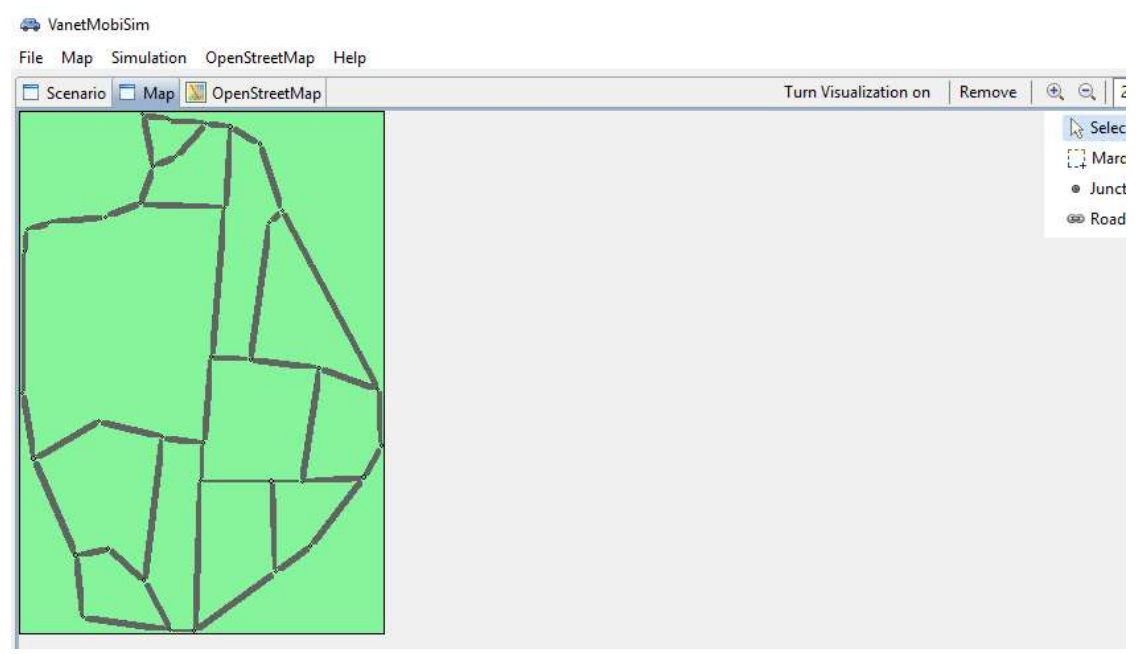

Gambar 2. Hasil Pembuatan Peta dengan User Graph

Algoritma penentuan rute yang digunakan dalam penelitian ini adalah Algoritma Speed Path. Algoritma Speed Path adalah algoritma pemilihan rute perjalanan dengan waktu tercepat. Algoritma Speed Path menunjukkan perilaku pengendara yang mencari waktu tempuh lebih cepat. Algoritma Speed Path digunakan untuk skema pengimbangan beban trafik kendaraan, dapat dilihat pada Gambar 3. Node / kendaraan akan memilih jalur yang tersedia dengan waktu tempuh yang lebih cepat, tidak terpaku pada satu jalur yang terpendek.

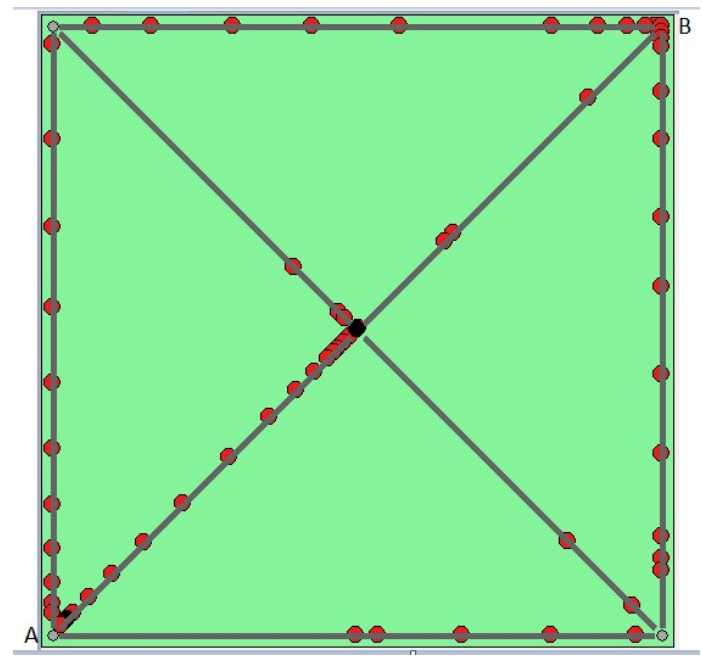

\section{Gambar 3. Model Mobilitas Algoritma Speed Path}

Pada simulasi, kendaraan akan dilewatkan pada satu jalur, kemudian dengan IDM-IM yang telah diatur sebelumnya kendaraan/node akan menyebar ke jalur lain yang ada untuk mendapatkan waktu tempuh tercepat. Karakteristik trafik kendaraan adalah parameter yang membentuk karakteristik suatu jalan. Pada umumnya menggunakan satuan mobil penumpang (smp). Parameter ini diantaranya kecepatan rata-rata ( $\mathrm{km} / \mathrm{jam})$, volume kendaraan (smp/jam), dan intensitas trafik (smp/km). Untuk menentukan karakteristik kendaraan ini diperlukan dua data yaitu data kecepatan rata-rata kendaraan pada ruas jalan tertentu beserta dengan nilai kedatangan kendaraan tiap satuan waktu. Penelitian ini akan melihat dan menganalisis kinerja pada Vanet dengan perbedaan jumlah node dengan skema pengimbangan beban trafik kendaraan. Kecepatan rata-rata yang digunakan adalah 70 
$\mathrm{km} / \mathrm{jam}$ sesuai dengan standar minimun kecepatan pada Vanet. Jumlah node yang digunakan adalah 10, 20, 30, 40, 50, 60 ,70, 80, 90, dan 100 node (Setiabudi, Pratiwi, Ardiansyah, Perdana, \& Sari, 2016). Terdapat tiga ruas jalan yang digunakan pada penelitian ini yaitu Jalan Djuanda, Jalan Taman Sari, dan Jalan Dipatiukur Kota Bandung.

\subsection{Perancangan Model Jaringan}

Model jaringan merupakan subsistem yang didalamnya berkaitan dengan jaringan yang digunakan pada penelitian ini. Jaringan yang digunakan adalah jaringan ad-hoc antar kendaraan yaitu Vanet, oleh karena itu jaringan akan dirancang sesuai dengan karakteristik dan parameter yang ada pada jaringan Vanet. Perancangan model jaringan dilakukan menggunakan Network Simulator 2 (NS-2). Pembentukan subsistem jaringan ini terbagi menjadi 3 bagian yaitu spesifikasi jaringan VANET, trafik data dan routing protocol.

\subsubsection{Spesifikasi Jaringan Vanet}

Standar IEEE 802.11p dikenal sebagai Wireless Access in Vehicular Environments (WAVE) yang khusus dikembangkan untuk diaplikasikan pada jaringan Vanet. Standar ini juga dapat mendukung berbagai aplikasi pada Intelligent Transportation System (ITS). Perkembangan ini diantaranya pertukaran data antar kendaraan berkecepatan tinggi dengan kendaraan berkecepatan rendah dan infrastuktur jalan pada pita radio yang telah terlisensi untuk ITS (Abdeldime \& Wu, 2014). Pada NS2 telah tersedia file *.tcl yang menyediakan spesifikasi yang dibutuhkan untuk mengaplikasikan standar IEEE 802.11p pada simulasi. File yang dimaksud terletak pada direktori "../ns-allinone-2.35/ns-2.35/tcl/ex/802.11/IEEE802-11p.tcl" (Muhtadi, 2015).

\subsubsection{Trafik Data}

Penelitian ini menggunakan trafik data berupa Constant Bit Rate (CBR) yang dibangkitkan menggunakan script cbrgen.tcl. Pembangkitan trafik menggunakan script tersebut bersifat acak dengan distribusi seragam. Parameter yang dimasukan dalam script cbrgen.tcl adalah tipe koneksi, jumlah node, koneksi maksimal, laju paket, dan seed. Tipe koneksi yang digunakan adalah User Diagram Protocol (UDP). Alasan pemilihan tipe koneksi UDP ini karena umumnya untuk trafik yang berhubungan dengan keselamatan pada VANET adalah trafik yang ditumpangkan pada koneksi UDP sehingga dapat meminimalisir delay. Koneksi maksimal menentukan banyaknya koneksi maksimal yang terdapat pada jaringan pada satu waktu. Koneksi maksimal yang digunakan adalah 1 koneksi. Layanan yang digunakan adalah Data dengan packet size sebesar 512 bytes dan Voice sebesar 160 bytes (Cisco, 2016).

\subsubsection{Protokol Routing}

Protokol routing yang digunakan pada penelitian ini adalah protokol routing GPSR dan AODV. GPSR merupakan protokol routing yang bersifat position based / geographic based dan AODV merupakan protokol routing yang bersifat topology based, keduanya berada dalam dua subkelas yang berbeda. Hal tersebut yang mendasari peneliti memilih jenis protokol routing tersebut.

\subsection{Skenario Simulasi}

Skenario simulasi akan dibuat sedemikian sehingga dapat mencapai tujuan penelitian yaitu untuk mengetahui kinerja jaringan VANET. Dengan demikian dibuat 2 skenario secara umum yaitu scenario dengan routing protoco/ GPSR dan routing protocol AODV keduanya dengan kecepatan node $70 \mathrm{~km} / \mathrm{jam}$. Terdapat 40 skenario simulasi yang akan dilakukan pada penelitian ini yang merupakan kombinasi dari dua protokol routing, dua layanan yaitu voice dan data dan 10 jumlah node yang berbeda. Setiap skenario dilakukan 3 kali pengulangan untuk mendapat hasil yang valid. Secara rinci skenario simulasi dapat dilihat pada Tabel 1. 
Tabel 1. Skenario Simulasi

\begin{tabular}{|c|l|c|c|c|c|c|c|c|c|c|c|}
\hline \multirow{2}{*}{ RP } & \multirow{2}{*}{ Layanan } & \multicolumn{10}{|c|}{ Jumlah Node } \\
\cline { 3 - 13 } & & 10 & 20 & 30 & 40 & 50 & 60 & 70 & 80 & 90 & 100 \\
\hline \multirow{2}{*}{ GPSR } & Data & $\mathrm{S} 1$ & $\mathrm{~S} 2$ & $\mathrm{~S} 3$ & $\mathrm{~S} 4$ & $\mathrm{~S} 5$ & $\mathrm{~S} 6$ & $\mathrm{~S} 7$ & $\mathrm{~S} 8$ & $\mathrm{~S} 9$ & $\mathrm{~S} 10$ \\
\cline { 2 - 12 } & Voice & $\mathrm{S} 11$ & $\mathrm{~S} 12$ & $\mathrm{~S} 13$ & $\mathrm{~S} 14$ & $\mathrm{~S} 15$ & $\mathrm{~S} 16$ & $\mathrm{~S} 17$ & $\mathrm{~S} 18$ & $\mathrm{~S} 19$ & $\mathrm{~S} 20$ \\
\hline \multirow{2}{*}{ AODV } & Data & $\mathrm{S} 21$ & $\mathrm{~S} 22$ & $\mathrm{~S} 23$ & $\mathrm{~S} 24$ & $\mathrm{~S} 25$ & $\mathrm{~S} 26$ & $\mathrm{~S} 27$ & $\mathrm{~S} 28$ & $\mathrm{~S} 29$ & $\mathrm{~S} 30$ \\
\cline { 2 - 11 } & Voice & $\mathrm{S} 31$ & $\mathrm{~S} 32$ & $\mathrm{~S} 33$ & $\mathrm{~S} 34$ & $\mathrm{~S} 35$ & $\mathrm{~S} 36$ & $\mathrm{~S} 37$ & $\mathrm{~S} 38$ & $\mathrm{~S} 39$ & $\mathrm{~S} 40$ \\
\hline
\end{tabular}

\subsection{Parameter Simulasi}

Simulasi dilakukan dengan menggunakan perangkat lunak Network Simulator versi 2.35. Parameter simulasi ditentukan berdasarkan pada standar-standar yang digunakan pada jaringan VANET. Pada Tabel 2 diperlihatkan parameter-parameter yang digunakan dalam simulasi ini.

Tabel 2. Parameter Simulasi

\begin{tabular}{|l|l|}
\hline Sistem Operasi & Ubuntu 12.0432 bit pada VirtualBox pada Windows 1064 bit \\
\hline Simulator Jaringan & NS 2.35 \\
\hline Pembangkit Model Mobilitas & VanetMobiSim 2.0 \\
\hline Routing Protocol & GPSR, AODV \\
\hline Model Mobilitas Mikro & IDM-IM \\
\hline Algortima Pemilihan Rute & Algoritma Speed Path \\
\hline Jumlah Node (kendaraan) & $10,20,30,40,50,60,70,80,90$, dan 100 node \\
\hline Model Propagasi Gelombang & Two Ray Ground \\
\hline Mac Type & IEEE $802.11 \mathrm{p}$ \\
\hline Tipe Antena & Omni direksional \\
\hline Model antrian paket & Droptail \\
\hline Durasi Simulasi & 120 detik \\
\hline Trafik data & CBR \\
\hline
\end{tabular}

\section{HASIL DAN PEMBAHASAN}

Pada bagian pendahuluan telah dijelaskan bahwa penelitian ini mensimulasikan skenario Vanet dengan skema pengimbangan beban trafik kendaraan dengan routing protocol GPSR dan AODV. Untuk mencapai tujuan penelitian yaitu untuk menguji kinerja jaringan VANET maka digunakan parameter QoS seperti throughput, delay, dan packet delivery ratio (Kamini \& Kumar, 2010). Dalam penjelasan selanjutnya digunakan sepuluh perubahan jumlah node yaitu 10, 20, 30, 40, 50, 60, 70, 80, 90, 100 nodes.

\subsection{Pengukuran Throughput}

Throughput adalah laju data rata-rata yang berhasil diterima oleh penerima (Kaur \& Kaur, 2013). Throughput didefinisikan sebagai jumlah data yang telah berhasil diterima per satuan waktu dari satu node ke node yang lain (Singh \& Verma, 2013). Parameter ini menggambarkan seberapa besar sebenarnya laju data yang dapat dikirim melalui suatu jaringan. Throughput diukur dalam satuan ukuran data per waktu. Satuan yang biasa digunakan adalah bit per detik. 


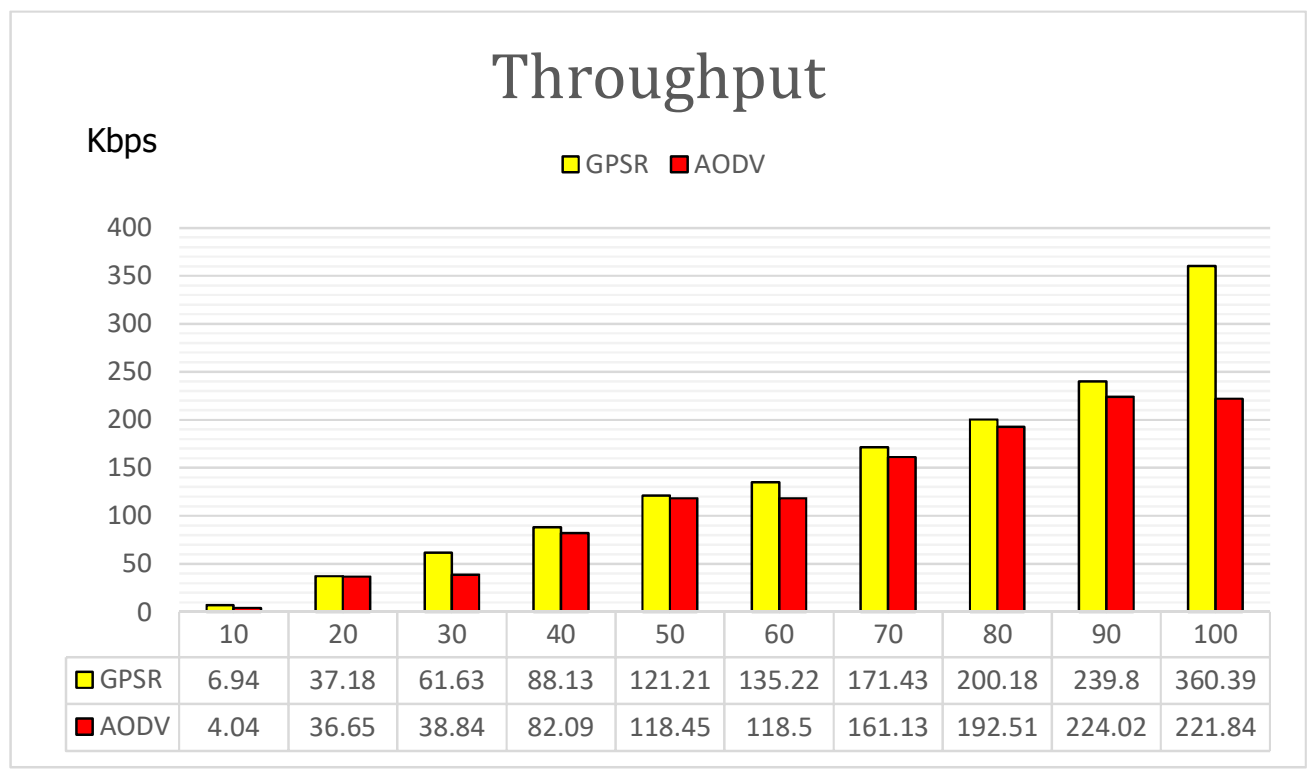

Gambar 4. Grafik Throughput dengan Layanan Data

Pada Gambar 4 adalah nilai throughput pada layanan Data dengan perubahan jumlah node kendaraan. Pada grafik dapat dilihat pada kedua routing protokol semakin banyak jumlah node nilai throughput yang dihasilkan cenderung naik.

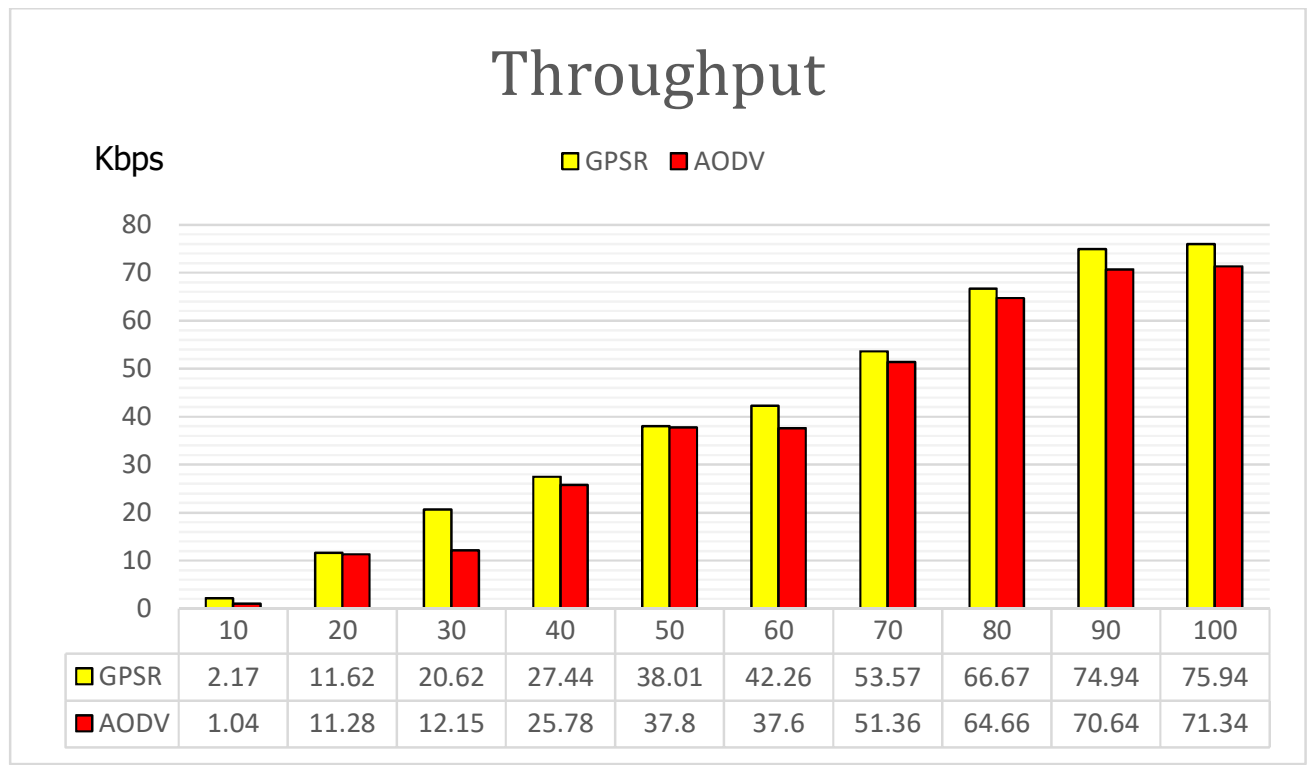

Gambar 5. Grafik Throughput dengan Layanan Voice

Pada Gambar 5 adalah grafik nilai throughput dengan layanan Voice dengan perubahan jumlah node. Nilai throughput cenderung naik dengan semakin besarnya jumlah node.

Nilai throughput pada routing protocol GPSR mengalami peningkatan seiring dengan meningkatnya jumlah node. Hal ini disebabkan karena semakin banyak node tetangga yang ada akan semakin mudah GPSR untuk menggunakan mode Greedy Forwarding dalam mengirimkan paket, yang mana location service akan memberikan data mengenai next hop 
node. Semakin banyak node maka akan semakin banyak probabilitas next hop node ditemukan, dengan semakin banyak next hope ditemukan maka jalur pengiriman paket akan semakin mudah terbentuk dan paket akan semakin banyak yang dapat dikirim. Pada routing protocol AODV nilai throughput juga memiliki kecenderungan meningkat. Hal ini disebabkan karena AODV menggunakan routing table dalam pengiriman paketnya. Pada saat node sumber akan mengirim paket, AODV akan melakukan update routing table agar ditemukan dan dibentuk jalur pengiriman ke node tujuan. Dengan semakin banyak jumlah node maka path/jalur akan semakin mudah ditemukan dan paket akan lebih banyak dikirimkan. Semakin banyak paket yang diterima maka akan semakin bagus nilai throughput. Dilihat dari grafik Gambar 4 dan 5, secara garis besar performansi routing protocol GPSR lebih baik daripada AODV, karena GPSR menggunakan coordinat di setiap nodenya, sehingga pengiriman paket akan lebih mudah. Sedangkan AODV menggunakan routing table dalam pengiriman paketnya, diperlukan pencarian path/link terlebih dahulu untuk paket mencapai tujuan.

\subsection{Pengukuran Pakcet Delívery Ratio}

Packet Delivery Ratio (PDR) adalah nilai yang menggambarkan perbandingan antara jumlah paket yang dikirim dengan jumlah paket yang berhasil sampai tujuan (Denatama, Perdana, \& Negara, 2016). Nilai PDR akan serupa dengan nilai throughput karena samasama menggambarkan kesuksesan pengiriman paket (Febryan, Perdana, \& Dewanta, 2016).

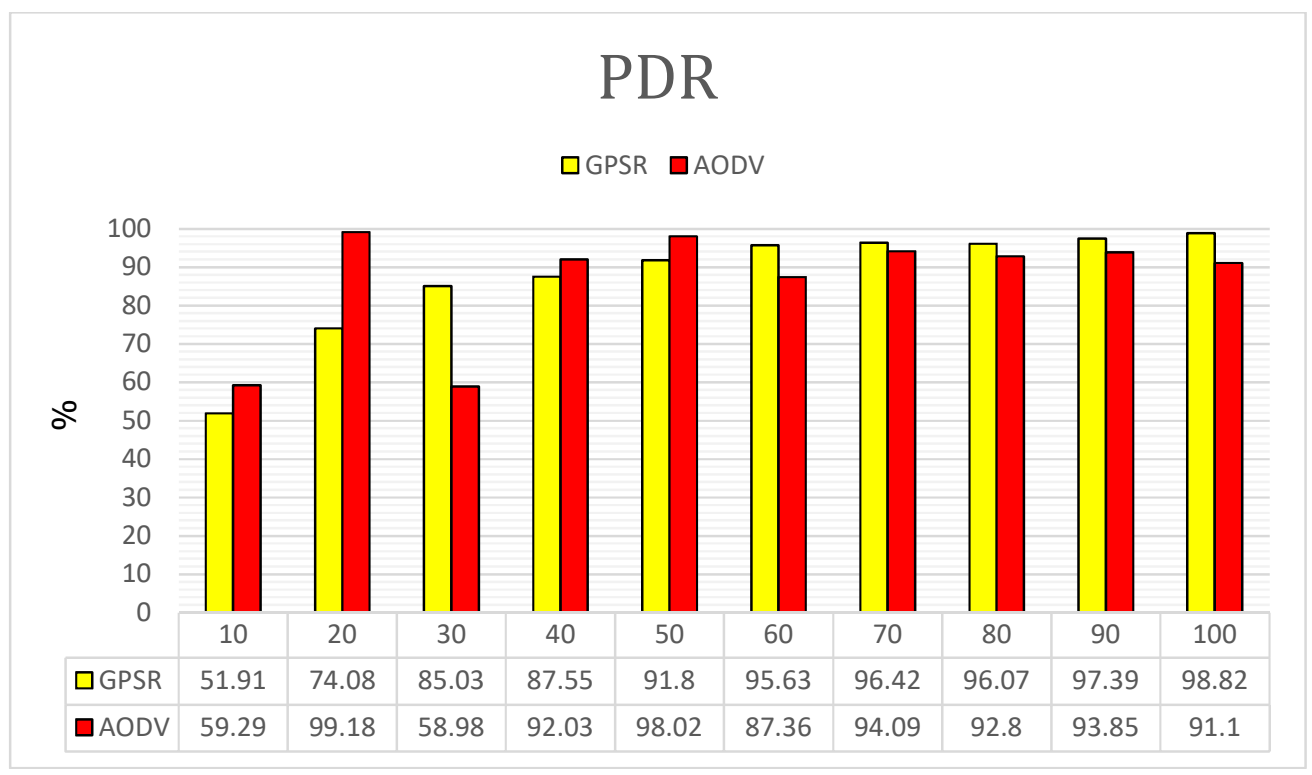

Gambar 6. Grafik PDR dengan Layanan Data

Gambar 6 adalah nilai PDR pada layanan Data dengan perubahan jumlah node kendaraan. Pada grafik dapat dilihat routing protokol AODV semakin banyak jumlah node nilai PDR yang dihasilkan cenderung fluktuatif namun cenderung meningkat, hal tersebut disebabkan karena perubahan topologi jaringan seiring dengan perubahan jumlah node yang menyebabkan perubahan jalur routing yang berubah-ubah. Pada routing protokol GPSR semakin banyak jumlah node, nilai PDR yang dihasilkan cenderung meningkat. 


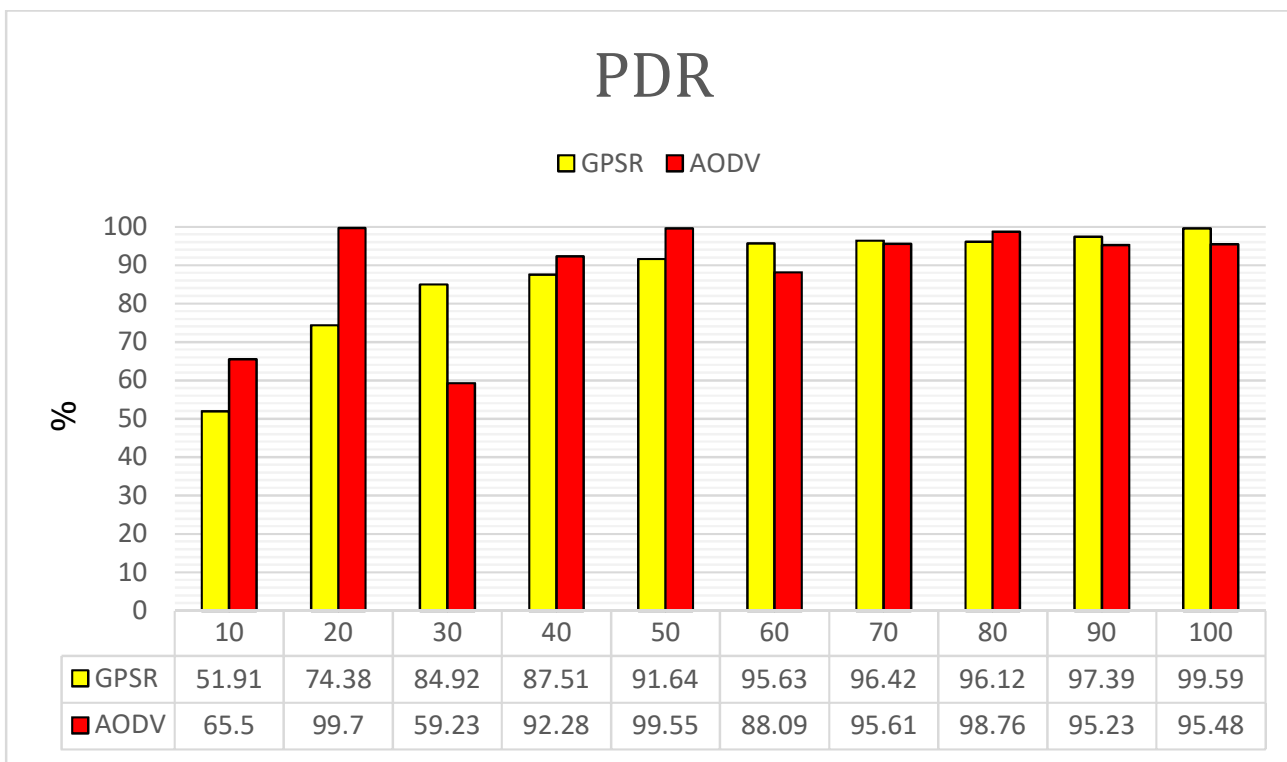

Gambar 7. Grafik PDR dengan Layanan Voice

Pada Gambar 7 adalah nilai PDR pada layanan Voice dengan perubahan jumlah node kedaraan. Pada grafik dapat dilihat nilai PDR memiliki kecenderungan yang sama dengan pada layanan data. Pada routing protocol GPSR nilai PDR memiliki kecenderungan naik. Seperti yang telah dijelaskan sebelumnya, semakin banyak jumlah node maka semakin banyak node tetangga yang membantu menemukan node tujuan sehingga lebih banyak paket yang diterima. Begitu juga dengan AODV, dengan penambahan jumlah node, maka path/ link semakin mudah ditemukan, sehingga paket akan lebih banyak yang diterima. Nilai PDR akan berbanding lurus dengan nilai throughput. Dari hasil simulasi nilai PDR meningkat maka nilai throughput juga meningkat. Dilihat dari hasil simulasi pada grafik Gambar 6 dengan nilai rata-rata PDR $87.47 \%$ untuk GPSR dan $86.67 \%$ untuk AODV, secara keseluruhan performansi GPSR lebih baik dari AODV.

\subsection{Pengukuran End-to-End Delay}

End to end delay adalah rentang waktu antara suatu paket dikirim hingga paket tersebut mencapai tujuan (Tonapa, Rahmiati, \& Komba, 2014). Delay ini juga termasuk di dalamnya delay propagasi, delay antrian, dan waktu route discovery (Singh \& Verma, 2013). Parameter delay sangat penting karena banyak aplikasi VANET nantinya yang akan membutuhkan delay seminimal mungkin terutama pada aplikasi yang berhubungan dengan keselamatan.

Pada Gambar 8 adalah nilai delay pada layanan Data dengan perubahan jumlah node kedaraan. Pada grafik dapat dilihat pada kedua routing protokol semakin banyak jumlah node nilai delay yang dihasilkan cenderung naik. 


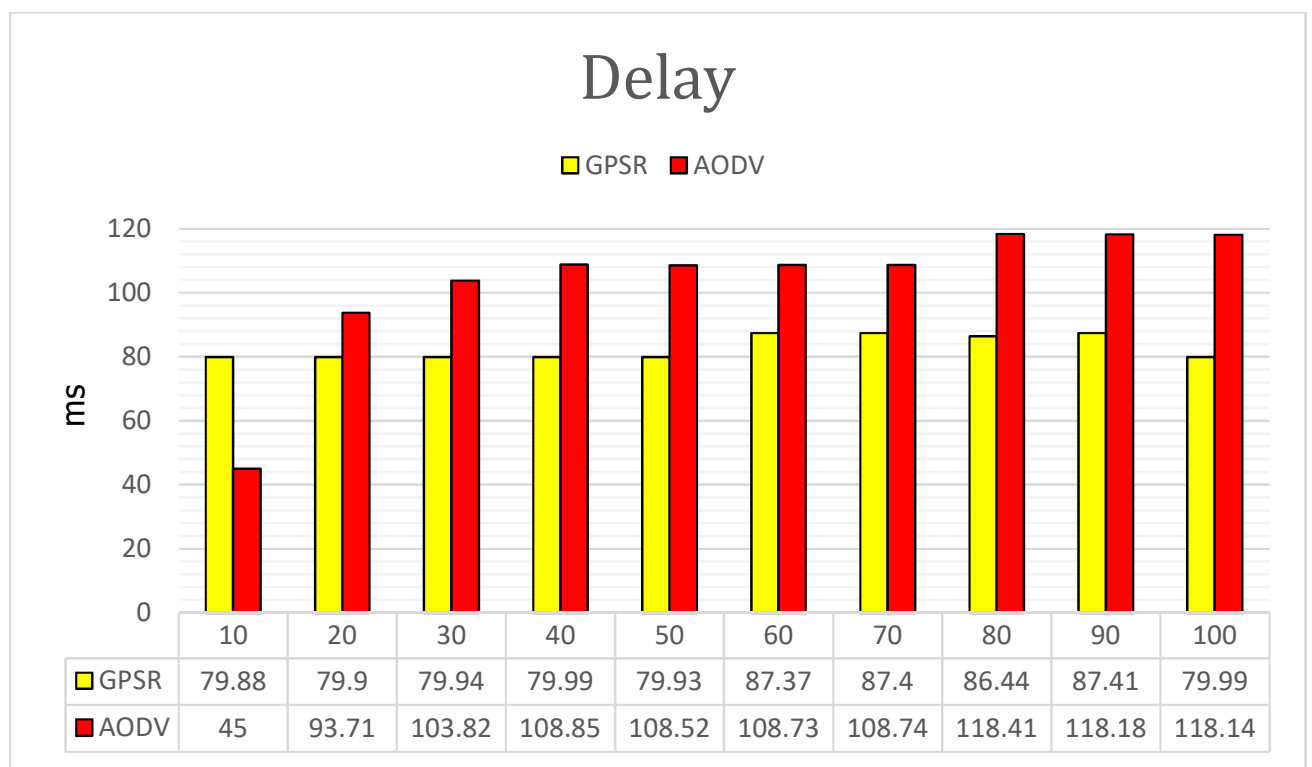

Gambar 8. Grafik Delay dengan Layanan Data

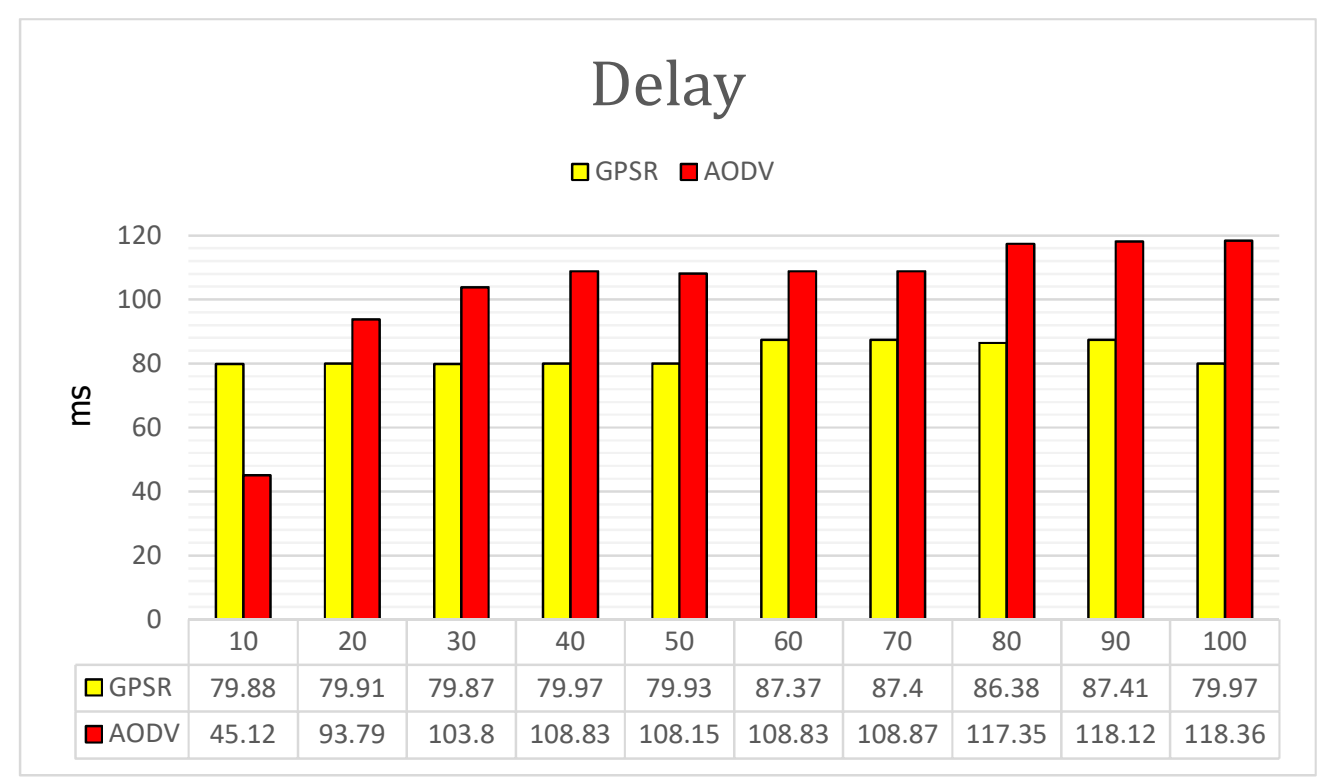

\section{Gambar 9. Grafik Delay dengan Layanan Voice}

Pada Gambar 9 adalah nilai delay pada layanan Voice dengan perubahan jumlah node kendaraan. Pada grafik dapat dilihat pada kedua routing protokol semakin banyak jumlah node nilai delay yang dihasilkan cenderung naik. Nilai delay yang dihasilkan cenderung naik ketika jumlah node semakin besar. Hal tersebut dikarenakan semakin banyak jumlah node maka akan semakin banyak node yang dilewati dari pengirim ke penerima. Semakin banyak node yg dilewati maka akan semakin banyak waktu yang dibutuhkan. Nilai delay antara GPSR dan AODV secara keseluruhan lebih besar nilai delay AODV. Hal tersebut karena AODV menggunakan routing table dalam pengiriman paketnya, sehingga pada saat pengiriman paket node sumber harus melakukan route discovery terlebih dahulu untuk menemukan jalur pengiriman paket tersebut. Hal tersebut membutuhkan waktu yang lebih banyak, sehingga nilai delay akan semakin besar. 


\section{KESIMPULAN}

Penelitian mengenai performansi GPSR dan AODV dengan skema pengimbangan beban trafik ini menghasilkan kesimpulan sebagai berikut:

1. Model mobilitas dengan skema pengimbangan beban trafik kendaraan dirancang menggunakan software VanetMobiSim versi 2.0 pada system operasi Windows. Pada VanetMobiSim digunakan algoritma Speed Path untuk membuat skema pengimbangan beban trafik kendaraan.

2. Kinerja jaringan VANET dengan skema pengimbangan beban trafik kendaraan dapat dilihat dari nilai parameter-parameter QoS (throughput, PDR, delay).

3. Nilai rata-rata untuk metrik performansi throughput pada routing protocol GPSR dan AODV masing-masing untuk layanan Data sebesar $142.21 \mathrm{Kbps}$ dan $119.81 \mathrm{Kbps}$. Dan untuk layanan Voice masing-masing sebesar $41.32 \mathrm{Kbps}$ dan $38.36 \mathrm{Kbps}$.

4. Nilai rata-rata untuk metrik performansi PDR pada routing protocol GPSR dan AODV masing-masing untuk layanan Data sebesar $87.47 \%$ dan $86.67 \%$. Dan untuk layanan Voice masing-masing sebesar $87.55 \%$ dan $88.94 \%$.

5. Nilai rata-rata untuk metrik performansi delay pada routing protocol GPSR dan AODV masing-masing untuk layanan Data sebesar 82.83 ms dan $103.21 \mathrm{~ms}$. Dan untuk layanan Voice masing-masing sebesar $82.81 \mathrm{~ms}$ dan $103.12 \mathrm{~ms}$.

6. Secara keseluruhan berdasarkan skenario perubahan jumlah node dengan skema pengimbangan beban pada VANET, routing protoco/ GPSR mendapatkan nilai parameter QoS (throughput, PDR, delay) yang lebih baik dari AODV.

7. Perubahan jumlah node berpengaruh pada kinerja VANET dengan menggunakan dua routing protocol diatas. Semakin banyak jumlah node maka nilai PDR, throughput dan delay akan semakin besar.

\section{DAFTAR RUJUKAN}

Jerome, H., Marco, F., Fethi, F., \& Christian, B. (2009). Vehicular Mobility Simulation with. The Society for Modeling and Simulation International.

LAB-KBJ. (2016, March 29). Mengenal teknologi VANET. (Institut Teknologi Sepuluh Nopember Surabaya) Retrieved September 12, 2016, from http://kbj.if.its.ac.id/mengenal-teknologi-vanet/

Muhtadi, A., Munadi, R., \& Perdana, D. (2015). Evaluasi Kinerja DSDV, AODV, dan ZRP Pada VANET dengan Skema Pengimbangan Beban Trafik Kendaraan. Bandung, Indonesia: School of Engineering, Telkom University.

Perdana, D., \& Sari, R. F. (2015). Performance Evaluation Of Corrupted Signal Caused By Random Way Point and Gauss Markov Mobility Model on IEEE 1609.4 Standards. IEEE, 1.

Setiabudi, A., Pratiwi, A. A., Ardiansyah, Perdana, D., \& Sari, R. F. (2016). Performance Comparison of GPSR and ZRP Routing Protocols in VANET Environment. IEEE Region 10 Symposium (TENSYMP), Bali, Indonesia, (pp. 44-45).

Abdeldime, M. A., \& Wu, L. (2014). The Physical Layer of the IEEE 802.11p W AVE Communication Standard: The Specifications and Challenges. Proceedings of the 
World Congress on Engineering and Computer Science 2014 Vol II. San Francisco, USA.

Cisco. (2016, February 22). Voice Over IP - Per Call Bandwidth Consumption. Retrieved from Cisco: http://www.cisco.com

Kamini, \& Kumar, R. (2010). VANET Parameters and Applications: A Review. Global Journal of Computer Science and Technology, 10(7), 2.

Kaur, S., \& Kaur, S. (2013). ANALYSIS OF ZONE ROUTING PROTOCOL IN MANET. International Journal of Research in Engineering and Technology, 2(09), 3.

Singh, A., \& Verma, A. K. (2013). SIMULATION AND ANALYSIS OF AODV, DSDV, ZRP IN VANET. International Journal in Foundations of Computer Science \& Technology, $3(5), 22$.

Denatama, M. I., Perdana, D., \& Negara, M. N. (2016). Analisis Perbandingan Kinerja Protokol Routing DSDV dan OLSR Untuk Perubahan Kecepatan Mobilitas pada Standar IEEE 802.11ah. Jurnal Infotel, 8(2), 103.

Febryan, Perdana, D., \& Dewanta, F. (2016). Analisa Performasi Pengimbangan Beban Trafik Kendaraan menggunakan Vanet. Bandung: School of Electrical Engineering Telkom University.

Tonapa, O., Rahmiati, P., \& Komba, D. (2014). Analisis Performansi Konektifitas Pada Jaringan Wireless Broadband di Bandung. Jurnal Elkomika, 2(2), 168. 